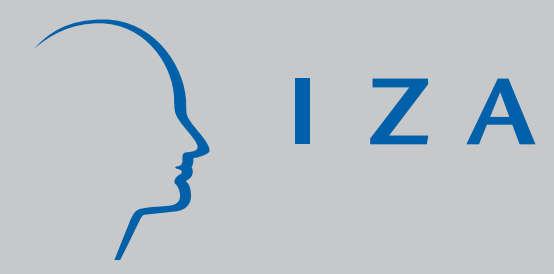

IZADP No. 2838

Are Ireland's Immigrants Integrating into its Labour Market?

Alan Barrett

David Duffy

J une 2007 


\title{
Are Ireland's Immigrants Integrating into its Labour Market?
}

\author{
Alan Barrett \\ Economic and Social Research Institute \\ and IZA \\ David Duffy \\ Economic and Social Research Institute
}

Discussion Paper No. 2838

June 2007

IZA

P.O. Box 7240

53072 Bonn

Germany

Phone: +49-228-3894-0

Fax: +49-228-3894-180

E-mail: iza@iza.org

\begin{abstract}
Any opinions expressed here are those of the author(s) and not those of the institute. Research disseminated by IZA may include views on policy, but the institute itself takes no institutional policy positions.

The Institute for the Study of Labor (IZA) in Bonn is a local and virtual international research center and a place of communication between science, politics and business. IZA is an independent nonprofit company supported by Deutsche Post World Net. The center is associated with the University of Bonn and offers a stimulating research environment through its research networks, research support, and visitors and doctoral programs. IZA engages in (i) original and internationally competitive research in all fields of labor economics, (ii) development of policy concepts, and (iii) dissemination of research results and concepts to the interested public.
\end{abstract}

IZA Discussion Papers often represent preliminary work and are circulated to encourage discussion. Citation of such a paper should account for its provisional character. A revised version may be available directly from the author. 


\section{ABSTRACT}

\section{Are Ireland's Immigrants Integrating into its Labour Market?*}

Ireland has experienced a remarkable change in its migratory patterns in recent years and has moved from experiencing large-scale emigration to receiving significant inflows. In this paper, we use data from a nationally representative sample of immigrants and natives drawn in 2005 to assess the occupational attainment of immigrants in Ireland relative to natives. It is found that immigrants, on average, are less likely to be in high-level occupations controlling for factors such as age and education. When looked at by year of arrival, it appears as if immigrants who arrived more recently have lower occupational attainment relative to earlier arrivals, thereby suggesting a process of integration. However, a closer analysis shows that the observation of better occupational attainment for earlier arrivals can be explained by a change in the national origin mix of Ireland's immigrants, with immigrants from the New Member States of the European Union having the lowest occupational attainment. Within national groups there is generally no clear evidence of improved occupational attainment over time.

JEL Classification: J61

Keywords: immigrants, labour market integration, Ireland

Corresponding author:

Alan Barrett

Economic and Social Research Institute

Whitaker Square

Sir John Rogerson's Quay

Dublin 2

Ireland

E-mail: Alan.Barrett@esri.ie

\footnotetext{
* We would like to acknowledge the helpful comments of John FitzGerald, David Jaeger, Brian Nolan, Philip O'Connell and participants at a seminar at the ESRI.
} 


\section{Are Ireland's Immigrants Integrating into its Labour Market?}

\section{Section 1: Introduction}

In his influential paper published in 1978, Chiswick appeared to show that the wages of immigrants converged on those of natives as they spent longer in the host country. Since then, the issue of immigrant integration in the labour market of their host countries has received further attention (for example, Borjas 1985, and, more recently, Amuedo-Dorantes and de la Rica, 2006). In this paper, we add to the literature by exploring the issue in the context of one of the world's new immigrant-receiving countries, Ireland. Having undergone a rapid economic transformation in recent years, Ireland has also seen a remarkable change in its migration patterns. From being a country of emigrants, Ireland is now a recipient of significant inflows. This provides migration researchers with a new laboratory to explore issues, including that of integration.

While many studies show immigrants experiencing labour market disadvantages relative to natives, this is unsurprising in the case of newly arrived immigrants. These new arrivals may lack location-specific human capital such as language and knowledge of the local labour market. Hence, it would be expected that their earlier period in the host country would see them earning less or holding lower level jobs. Concerns arise, however, for the immigrants themselves and for the host countries if immigrants are unable to overcome these initial disadvantages. A failure to integrate into the labour market, by which we mean that immigrants experience the same levels of labour market success as comparable natives, can result in immigrants becoming an excluded minority with implications for social cohesion. The persistence of immigrants in lower paid and less skill-intensive occupations may also lead to a productivity loss for the host economy.

We look at the issue of labour market integration by drawing on a large-scale nationally representative sample of immigrants and natives in Ireland drawn in 2005. As the data include information on the occupations of respondents, we use this as an indicator of labour market position. As the data also include information identifying immigrants and the year in which they arrived in Ireland, we are able to compare labour market outcomes across immigrants and natives, and across immigrants by 
year of arrival. We should note that although we have information on whether the individuals are unemployed, we do not analyse the move between unemployment and employment as another indicator of immigrant integration, as is done by AmuedoDorantes and de la Rica (2006) and by Antecol et al (2003). The reason for this is that immigrants in Ireland show no statistically significant differences in terms of unemployment propensity relative to natives ${ }^{2}$. However, as will be seen below, patterns of occupational attainment differ across immigrants and natives and across different categories of immigrants.

While the data allow us to generate insights into labour market outcomes across recent arrivals and earlier arrivals, we need to be cautious in interpreting any patterns. As we are not using panel data we cannot tell, for example, if any patterns of improved labour market outcomes are the result of integration, cohort effects or selective out-migration. Repeated cross-sections can sometimes be used to construct "synthetic cohorts" (see, for example, Borjas, 1987) but this is not possible with the data used below. Although the data have been collected on a quarterly basis since 1997, information on the year of arrival of immigrants is only available to us for the 2005 Quarter 2 Survey. In spite of these limitations, the data do allow us to uncover a number of interesting findings.

The paper is structured as follows. In Section 2, we discuss some important features of Ireland's recent experience of immigration by way of providing a context for the subsequent analysis. In Section 3, we briefly set out some of the main papers on the topic of immigrant integration and in particular a paper by Chiswick, Lee and Miller et al (2005). Our analysis is based on the approach taken in that paper and so it is useful to describe it. In Section 4 we describe the data and present the results. We conclude in Section 5.

\section{Section 2: Ireland's Recent Immigration Experience}

We will begin this brief review of Ireland's recent migration experience by drawing on Figure 1 which shows net inflows and outflows to and from Ireland over the last

\footnotetext{
${ }^{2}$ This finding of there being no difference in the probability of being unemployed across immigrants and natives is interesting in itself. It suggests that Ireland is absorbing immigrants very successfully in terms of employment.
} 
twenty years. A number of points can be distilled from the figure. As recently as the late 1980s, Ireland was a country of emigration. As can be seen from the negative flows in the figure, Ireland was losing over 40,000 of its population per annum in the late 1980s. As the population at that time was about 3.5 million, population losses of over 40,000 amounted to over 1 percent of the population. For the decade 1981 to 1991, the net outflow was over 200,000 or almost 6 percent of the population.

\section{Figure 1 here}

Around the mid-1990s, the economy of Ireland experienced a rapid turnaround and began to experience the highest growth rates in Europe ${ }^{3}$. As a consequence of this, the population outflows were reversed and net inflows began. Initially, the inflows were made up of roughly equal proportions of non-Irish immigrants and former Irish emigrants returning to Ireland. Since the mid-1990s these inflows have generally increased and the national mix has shifted from being 50 percent Irish to being about 20 percent Irish. From 2004, an acceleration in the inflow has been seen due to the ten New Member States of the EU (referred to hereafter as EU-NMS) being given full access to the Irish labour market. In the year ended April 2006, 86,000 people arrived in Ireland, with almost 40,000 of them being from the EU-NMS. Ireland was one of only three existing members of the EU to allow full access to its labour market to the EU's new citizens from the date of accession. The other two were Sweden and the UK.

As regards the administrative measures underpinning immigration into Ireland, there are a number of strands. First, all citizens of EU countries (with the exception of Bulgaria and Romania) are free to work in Ireland without restriction. Second, for non-EU members, a work-permit system operates. In essence, if an employer can show that no EU citizen is available to fill a vacancy, they can apply for a work permit and can recruit a non-EU national ${ }^{4}$. Since the opening up of the labour market to all EU citizens in 2004, the number of new work permits issued has fallen. For example, in 2003 almost 22,000 new permits were issued. In 2006, this had fallen to

\footnotetext{
${ }^{3}$ For an analysis of Ireland's economic turnaround, see Walsh and Honohan (2002)

${ }^{4}$ At the time of writing, a new system of admission was being legislated for which would operate along the lines of a "greencard" system for certain immigrants, typically the more highly skilled. However, this new system is not relevant for the immigrants analysed here as the data were collected in 2005.
} 
6,300 and was a direct result of the government's decision to balance the opening up of the labour market to the New Member Sates with a more conservative approach to work permit numbers. Refugees have full entitlements to work but this is not the case for asylum seekers whose cases are being dealt with. They are generally not allowed to work and so must rely on state transfers.

Existing research looking at the labour market characteristics of immigrants in Ireland and their experiences has produced a number of insights. Ireland's immigrant population is a highly educated one, with the proportion of degree holders exceeding that of the domestic population (Barrett et al, 2006; Minns, 2005). However, they do not appear to be accessing jobs that fully reflect their education levels (Barrett et al, 2006) and appear to be earning significantly less than comparable natives (Barrett and McCarthy, 2006). The findings with respect to poor labour market outcomes could well be the result of the relatively recent arrival of most immigrants as they are likely to be lacking location specific human capital such as language skills. None of these papers have had access to data on the year of arrival for the immigrants and so none have been able to shed any light on the issue of integration.

We noted in the Introduction that Ireland has become a new laboratory for the study of migration. It is useful here, in the light of the discussion of the nature of immigration into Ireland, to set out what makes Ireland of particular interest for migration researchers. First, as inward migration into Ireland has occurred over a period when the economy has been growing at an exceptionally high rate, the economic conditions have been favourable for immigrant success in the labour market. Second, as much of the immigration into Ireland has been from other European countries, many of Ireland's immigrants will not be subject to multiple forms of possible discrimination such as those based on religion or skin colour. Both of these factors should operate in a way that would see immigrants in Ireland doing relatively well when compared to natives.

A third useful feature of immigration into Ireland is the concentration of Eastern Europeans in the latest inflow. This allows us to generate insights into this new source of population movements, namely from the new EU to the old EU. By generating insights on who these new immigrants are and how they are performing in their host 
countries, we can draw conclusions on the possible impacts of emigration from the EU-NMS.

\section{Section 3: Literature on Integration}

Chiswick et al (2005) provide a useful framework in which to analyse immigrant integration so we will set out the details. In their model, immigrants experience a " $U$ shaped” pattern of occupational attainment. In moving between their last job in their home country and the first job in the host country, immigrants are likely to experience downward occupational mobility. As their skills are unlikely to be directly transferable to the new setting, they may need to work in lower level occupations at the point of their arrival in the host country. As time goes on, the immigrants will acquire location-specific human capital and this will allow them to move up the occupational ladder. In time, they may be able to move into an occupation at the same level as the one they left. By plotting their occupational attainment over time, the Ushape is seen.

According to Chiswick et al (2005), the pattern just described should be particularly pronounced for high-skilled immigrants and for immigrants from countries where skills are less readily transferable to the host. In the case of high-skill immigrants, there is more room to drop down the occupational ladder when migrating and more scope for upward mobility following migration, relative to less-skilled immigrants. In the case of immigrants from countries with very different labour markets, the move from one country to another is more likely to involve downward mobility but, as with high-skilled immigrants, as location-specific human capital is acquired, upward mobility is possible.

We should note that unlike Chiswick et al (2005), our data do not allow us to observe immigrants before they migrate and neither do we have longitudinal data. As such, we cannot test the hypotheses in the manner undertaken in the 2005 paper. Nonetheless, as we have data on immigrants by year of arrival, we can think in terms of immigrant outcomes differing according to the length of time spent in Ireland and explore how they differ, for example, across skill groups. In so doing, we are mindful not to make strong conclusions in respect of integration over time based our cross-sectional data as other forces, such as selective out-migration, could be at work. 
Chiswick et al (2005) find evidence of occupation integration for immigrants in Australia. For example, those with higher levels of pre-immigration skills were found to show greater improvements in occupational status, within a timeframe of three years and six months. For Spain, Amuedo-Dorantes and de la Rica (2006) show that immigrants from the EU do not display any occupational disadvantage relative to natives, which appears supportive of the Chiswick et al (2005) hypotheses on migration between similar countries. They also find evidence of integration among other European immigrants and Latin Americans but not among African immigrants. Green (1999) finds evidence of occupational mobility among immigrants to Canada but the precise pattern of mobility was not consistent with a general pattern on integration. Much of the mobility observed by Green occurred in the late 1980s but not at other times. In addition, immigrants with different lengths of time in Canada appeared to experience the same type of mobility in the late 1980s. This suggested to Green that what was observed was a different reaction to economic events in the late 1980s for immigrants relative to natives. Many other studies have looked at the issue of immigrant integration but through earnings as opposed to occupation. Among these papers are Baker and Benjamin (1994) and Borjas (1985), both of which found little evidence of integration.

\section{Section 4: Data and Results}

4(a) - Data

The data used in the analysis are from the Quarterly National Household Survey (quarter 2 of 2005, referred to from here on as QNHS). The survey is undertaken by Ireland's official statistical agency, the Central Statistics Office (CSO). The main purpose of the QNHS is to produce quarterly official information on labour market variables such as employment, unemployment and participation. Throughout the year 3,000 households are surveyed each week; hence each quarterly sample contains 39,000 households ${ }^{5}$. The CSO make the micro-data available, although some of the collected data is omitted or aggregated. The sample has over 91,000 observations, which amounts to over 2 percent of the population. We only look at labour force

\footnotetext{
${ }^{5}$ A full description of the sampling techniques can be found in CSO (2005).
} 
participants in our analysis and so the dataset on which we conduct the analysis contains just under 35,000 individuals.

Our next task is to set out precisely how we define "immigrants" and the groups of "natives" against which we will compare them. We define immigrants in the following way: people who describe their nationality as being other than Irish and were not born in Ireland. We only look at immigrants who arrived in Ireland in 1995 or later so that our attention is focused on immigrants who arrived in the context of Ireland's changed economic fortunes. We compare this group with people who describe themselves as Irish nationals and who say they were born here. This means we omit Irish nationals who were born outside of Ireland ${ }^{6}$. These selections, along with the omission of individuals for whom we do not have a complete set of data, produce two sub-populations - 32,536 natives and 1,634 immigrants. The immigrants are divided in five regional categories: UK, USA, EU-13 (i.e. the EU-15 less Ireland the UK), the New Member States of the EU and "other”. Specific country identifiers are not provided in the data, apart from the UK and the USA.

\section{4(b) - Results (descriptive)}

We begin our analysis of the occupational attainment of Ireland's immigrants by looking at the distribution of immigrants across occupational categories. In Table 1, we show the distribution for all immigrants (who have arrived since 1995) collectively and also by period of arrival. The distribution for the native population is also shown. A number of interesting points emerge.

If we compare the distributions of all immigrants and natives we see that immigrants are more heavily concentrated in the lower end of the distribution. While slightly over 40 percent of natives are in the top three occupational categories, the corresponding figure for all immigrants is 35 percent. However, if we look across the immigrants when they are grouped by year of arrival, a different picture emerges. The most recently arrived immigrants show the lowest degree of concentration in the top three

\footnotetext{
${ }^{6}$ Because of Ireland's long history of emigration, there is a small group of people living there who were born outside of Ireland to Irish parents and who then returned to Ireland. These people are not immigrants in the standard sense. However, as they may have spent significant time outside of Ireland between their births and when they came to live in Ireland, it would not be entirely correct to categorise them as natives. For this reason, we exclude them from the analysis
} 
occupational categories. This proportion increases for immigrants who arrived in earlier periods. For those who arrived in the period 1995-1999, the proportion in the top three occupational groups exceeds that of natives.

\section{Table 1 here}

The pattern shown in Table 1 is consistent with an integration story but it is clear that other explanations could underpin the pattern and so it is necessary to explore this much further. Before moving on to the regression analysis below, we can look at other possible explanations for this apparent integration, namely, educational attainment and national mix $^{7}$. If the most recently arrived immigrants have lower levels of education, this would partly explain the pattern in Table 1 and what is observed is a compositional effect as opposed to integration. Similarly, if the most recent arrivals are more heavily drawn from countries whose immigrants generally do less well in Ireland's labour market, this too could partly explain the pattern in Table 1.

In Table 2, we show the educational distributions of immigrants and natives. Before looking at the immigrants by year of arrival, it should be noted that collectively immigrants in Ireland are a remarkably educated group. This point has emerged from analyses of earlier QNHSs (Barrett and Trace, 1998; Barrett et al, 2006) and also from an analysis of the 2002 Census (Minns, 2005). The most recently arrived immigrants have lower levels of education relative to the earliest arrivals so this may partly explain their lower level of occupational attainment relative to earlier arrivals. However, there is no difference between the 2000-01 group and the 1995-99 group and so education cannot explain the 8.5 percentage point gap in their proportions in the higher level occupations.

\section{Table 2 here}

In Table 3, we show the nationality distribution of immigrants by year of arrival and a striking picture emerges. In the period 1995-1999, over 50 percent of the immigrants arriving were from the UK, with only a small proportion (2.4 percent) coming from

\footnotetext{
${ }^{7}$ Of course, a changing national mix among immigrants could lead to a change in the educational attainment of immigrants.
} 
the countries which now make up the EU-NMS. In the most recent period, these proportions have been reversed, with over half of the new arrivals being from the EUMNS. Referring back to Chiswick et al (2005), if the thesis is correct that immigrants from countries that are similar to the host country will have better labour market outcomes, then this shift between the UK and the EU-NMS could explain the changing occupational pattern seen in Table 1.

\section{Table 3 here}

4(c) - Results (regression)

At this point, we will move beyond the descriptive statistics and will employ regression analysis to distil the relative impact of different factors on occupational attainment. The sets of regressions that are presented below are probit analyses in which the dependent variable is 1 if the individual is in one of three higher-level occupations shown in Table 1 and zero otherwise. Given this set up, we are modelling the likelihood of being in higher-level occupations based on a set of explanatory variables. These explanatory variables include dummy variables indicating age categories and educational categories, and also dummy variables indicating gender and marital status. We also include dummy variables indicating immigrants and natives, with the immigrants being further divided into different groups in later models. This approach is identical to that taken by Barrett et al (2006).

In Table 4, we present the results from a probit regression in which all immigrants and all natives are included. Rather than presenting coefficient estimates, we show the marginal impacts for each variable as these can be interpreted as differences in probabilities. Before discussing the immigrant marginal impact, we will take a brief look at the other variables in order to confirm that the model produces sensible results. For the age variables, the omitted category is people aged 15-19 years and so the positive and significant marginal impacts are what we would expect. For the education dummy variables the signs and significance are also as expected. The omitted category is "no formal qualifications". As can be seen from the marginal impacts, the likelihood of being in a higher-level occupation increases with level of education. Time with one's current employer also has a positive and significant impact. For the gender/marital status dummy variables, the omitted category is single 
female. A statistically significant difference is only found between single men and single women, with single men being less likely to be in high-level occupations.

\section{Table 4 here}

Turning to the immigrant dummy variable, the estimated marginal impact suggests that immigrants are 10 percent less likely to be in the higher level occupations, controlling for factors such as age and education. This repeats the finding of Barrett et al (2006) - using the 2003 QNHS, the immigrant dummy variable in the same probit model of occupational attainment was 7 percent. Barrett et al labelled this finding the “occupational gap” and pointed out that it implied a loss of output in the Irish economy as it suggested that immigrants were working below their full potential.

As the data that Barrett et al (2006) were working with did not identify the year of arrival for each immigrant, they were not able to explore if the "occupational gap” fell with years in Ireland. Our data allow us to examine this point. In Table 5, we show results from a probit regression which is similar to that shown in Table 4 but in which the immigrant group are broken up into four categories depending on their year of arrival. It should be noted that although the table only shows the coefficients on the immigrant dummy variables, the variables that are shown in Table 4 were included in the model.

\section{Table 5 here}

The first point to be taken from Table 5 is that immigrants in the arrival cohorts 200405, 2002-03 and 2000-01 all show lower probabilities of being in higher level occupations relative to natives, controlling for the factors shown in Table 3. However, the 1995-99 group are statistically as likely to be in higher-level occupations relative to natives. Although the marginal impacts decline across the arrival cohorts (as suggested by the descriptive statistics shown in Table 1), t-tests show no statistical differences between the three most recent arrivals. However, the marginal impacts for these three groups do differ statistically from the marginal impacts for the 1995-1999 group and so we can conclude that there is a difference in terms of occupational attainment between the earliest arrivals and those arriving more recently. 
The results in Table 5 are consistent with a process of immigrant integration in the labour market. However, the changing national mix (as shown in Table 3) could generate the same result if the national groups that make up a larger share of the most recent arrivals have lower levels of occupational attainment. For this reason, we re-ran the occupational attainment probit but this time replacing the year of arrival immigrant dummy variables with dummy variables indicating the immigrants' nationalities. The results are presented in Table 6 and a striking result emerges. Immigrants from the UK do not experience an "occupational gap” relative to natives. If anything, they experience an occupational advantage (albeit at the $10 \%$ level of statistical significance). In contrast, immigrants from the EU-NMS have the largest occupational disadvantage, at 23 percent.

\section{Table 6 here}

The results in Table 6 raise doubts about whether a process of immigrant integration is at work in Ireland but in order to examine it more closely, we need to control for the changing national mix of immigrants into Ireland. We do this by estimating probits with the same variables as used in the model in Table 5, i.e. the set of socioeconomic controls plus year-of-arrival indicators for immigrants, but comparing each national group of immigrants to natives in separate regressions. As we have five nationality groups, this leads to a set of five regressions. We only report the results for the UK and the EU-NMS here as these are the groups that dominated the inflows in the earliest and latest periods respectively. The results for the other three groups are discussed in brief below.

In Table 7, we present the results from a regression in which we estimate the occupational attainment of UK immigrants by years of arrival, relative to natives. As there is no discernable pattern in the size of the occupational gap (or advantage) over time, we cannot say that there is any evidence of assimilation. However, this would have been expected based on Chiswick et al (2005). As UK immigrants are coming from a similar country with similar labour market institutions, they should be able to find employment that is closely aligned to their skills. 


\section{Table 7 here}

In Table 8, we present the occupational attainment probit for the EU-NMS. It should be recalled from Table 6 that this group experienced the largest occupational gap. Our interest here is in seeing if it diminishes according to the year of arrival of the immigrants. The results show that this is not the case and that the occupational gap is generally quite consistent. The earliest arrivals appear to have identical occupational attainment relative to natives but the relevant cell size is too small for anything meaningful to be concluded. Hence, we are not finding evidence of integration. It could be that the time period over which we are observing the immigrants is simply too short to capture a pattern of integration. It could also be that our cell sizes, although allowing us to capture statistically significant differences between immigrants and natives, are not allowing us to capture within-immigrant differences. For these reasons, we need to stress that we all we can conclude is that we are not finding evidence of integration.

\section{Table 8 here}

Referring back again to Chiswick et al (2005), we would expect immigrants with higher levels of education to be more likely to experience upward occupational mobility. Based on this, we re-estimated the probit model for the EU-NMS immigrant but this time restricted the sample to those immigrants and natives with third level qualifications. The results are presented in Table 9 and a mixed picture emerges. The most recent arrivals show a large occupational gap relative to natives who also have third level qualifications. The measured occupation gap is also larger for the 2004/05 arrivals relative to the 2002/03 (the difference between the coefficients has a t-statistic of 2.16). However, the difference between the 2004/05 coefficient and the 2000/01 coefficient is not statistically significant. Hence, we are at best finding patchy evidence on integration, with immigrants from the EU-NMS who arrived in the period 2000/2002 still experiencing an occupation gap of almost 40 percent relative to comparable natives in 2005.

\section{Table 9 here}


Before leaving the issue of integration, we should note that little further evidence of such integration emerged from the analysis of the three other national groups - USA, EU-13 and "other". In general, there was no readily observable pattern in the occupational gap by year of arrival and even when there was, the differences in the coefficient estimates were not statistically significant. One small exception emerged when we ran the model for immigrants from the EU-13 with third level qualifications. The results are shown in Table 10. With the obvious exception of the earliest arrivals, we do see a declining occupational gap, with the difference between the 2004/04 and the 2000/01 groups being statistically significant (t-statistic is 1.98). However, this is relatively weak evidence of increased integration over time.

\section{Table 10 here}

\section{Section 5: Conclusion and Discussion}

The occupational attainment of Ireland's immigrants relative to natives, controlling for age and education, is lower for more recent arrivals. However, this does not appear to be the result of increased labour market integration over time. Instead, it is related to a changing national mix in the immigrant inflow into Ireland. Immigrants from the EU-NMS are heavily represented among the most recent arrivals and they suffer the largest occupational gap. In addition, there appears to be no lessening over time in the occupational gap experienced by immigrants from the EU-NMS. Hence, we are not finding evidence of immigrant labour market integration over time.

The focus of the analysis was on the occupational gap, controlling for age and education. In the context of our findings on that point, it is useful to return to an issue looked at above, namely, the educational distribution of immigrants. In Table 2, we looked at the distribution of educational qualifications by year of arrival. In Table 11, we again show the distribution of educational qualifications of immigrants but this time by nationality. The point that emerges is that immigrants from the EU-NMS have the lowest level of education attainment, as measured by the proportion with third level degrees. This implies that the changing national mix is contributing to a reduced educational attainment for the newest arrivals in Ireland (see Table 2) and also a lower occupational attainment controlling for education (see Table 5). 
With respect to educational qualifications, it should be noted that the proportion of immigrants with third level qualifications (31.8 percent) is identical to the proportion with third level qualifications in the native Irish population. For this reason, the conclusion should not be drawn that immigration into Ireland is becoming low skilled. Instead, the more modest conclusion can be drawn that the exceptionally high-skilled nature of Irish immigration, noted in earlier studies, is being weakened as a result of increased immigration from the EU-NMS. This policy-induced switch in the national origin mix of immigrants and the consequent change in human capital characteristics is reminiscent of the effects in the US of the 1965 Amendments to the Immigration and Naturalisation Act, as discussed in Borjas, 1987. As much of the analysis of the economic impacts of immigration to Ireland has been based on the inflow being highly-skilled (Barrett et al, 2002; Barrett et al, 2006), one implication of the findings here is that the estimates of the impacts may need to be re-estimated.

\section{Table 11 here}

These findings with respect to education and occupational attainment might be of more limited concern if evidence of increased integration over time was found but this is generally not the case. As these immigrants had been free to work in Ireland for a full year at the time the sample was drawn ${ }^{8}$, it is somewhat surprising that a greater degree of upward mobility was not found. It could be that the immigrants who arrived before 2004, i.e. before full rights to work applied, were working illegally and that a "scarring” effect has arisen whereby it is difficult to break out of a weak labour market situation. Other possible explanations for the lack of integration include language skills and the non-recognition of qualifications. It could also be that the timeframe is simply too short for integration to be observed. For this reason, it will be important to re-examine this issue as more data becomes available.

Whether the lack of integration is short-term or long-term, it is not possible to get a clear sense of what might be causing it from the data used here. However, it is important to highlight the possible existence of barriers to mobility in Ireland so that

\footnotetext{
${ }^{8}$ The New Member States entered the EU on 1 May, 2004; the data was collected in the Spring of 2005.
} 
any such barriers can be lowered, thereby allowing Ireland to avoid the difficulties experienced by other countries in terms of immigrant integration.

As a final point, is it useful to consider what these results tell us that is of specific relevance to the possible impacts of emigration for the EU-NMSs. In Table 11, we have shown that 31 percent of EU-NMS immigrants in Ireland have third level degrees. We know from Ireland's Census 2006 that immigrants from Poland are by far the largest group among the total immigrant group from the EU-NMS (63,000 out of a total of 120,000 ), so by comparing the 31 percent with the proportion of the Polish labour force which has a third level qualification, we can get a sense of whether emigration from Poland to Ireland is selective of the more skilled. As the corresponding figure for Poland is 16 percent (OECD, 2006), it certainly does appear as if Poland is losing a disproportionate share of its high-educated employees ${ }^{9}$.

Ireland itself experienced a "brain-drain" of this sort in the 1980s. However, when those who left in the 1980s returned in the 1990s, they appear to have returned with enhanced human capital, as evidenced by the higher earnings of returning migrants relative to non-migrants (Barrett and O’Connell, 2001). If the highly-skilled Polish emigrants return to Poland with similarly enhanced human capital, then the concerns surrounding the "brain-drain” phenomenon will be reduced. However, as the results here appear to show that immigrants from the EU-NMSs are not accessing higherskilled occupations, in which they would acquire enhanced skills and competencies, this positive effect may not arise.

\footnotetext{
${ }^{9}$ The only other NMS covered by the OECD data is Slovakia - the proportion of the labour force with third level education there is 13 percent.
} 


\section{Appendix}

Figure 1: Net Migration to and from Ireland 1987 to 2006

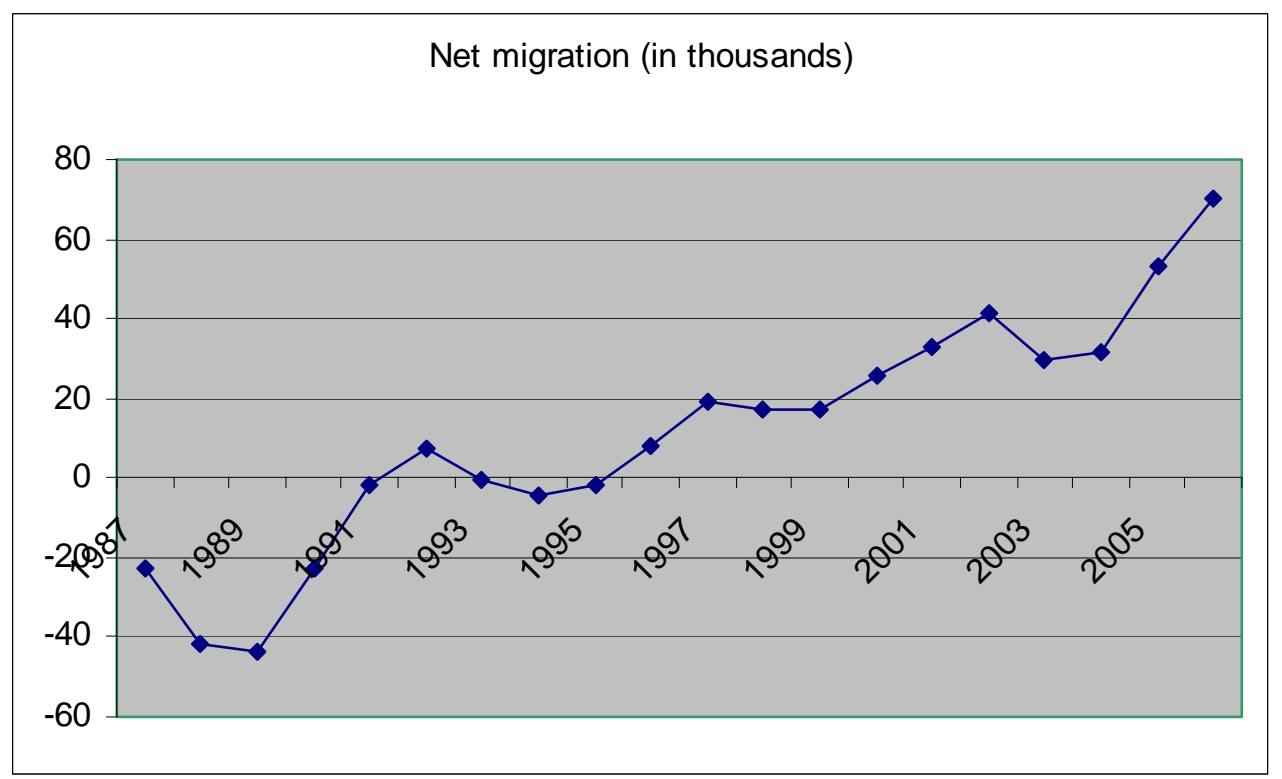

Table 1: Occupational Distributions of Immigrants and Natives

\begin{tabular}{lrrrrrr}
\hline & & All & Arrived & Arrived & Arrived & Arrived \\
& Native immigrants & $04-05$ & $02-03$ & $00-01$ & $95-99$ \\
\hline & $\%$ & $\%$ & $\%$ & $\%$ & $\%$ & $\%$ \\
Managers/administrators & 19.2 & 9.5 & 7.1 & 9.6 & 8.1 & 15.6 \\
Professional & 12.1 & 13 & 7.1 & 12.4 & 16.7 & 19 \\
Associate professional/ technical & 9.5 & 12.4 & 8.4 & 13.7 & 15.2 & 13.9 \\
Clerical and secretarial & 13.9 & 10.1 & 8.8 & 9.9 & 11 & 11.5 \\
Craft and related & 15.2 & 16.8 & 23.5 & 15.9 & 11 & 14.2 \\
Personal and protective service & 11.1 & 17.4 & 19.3 & 19 & 16.7 & 12.9 \\
Sales & 9.5 & 10.8 & 12.4 & 10.6 & 10.5 & 8.5 \\
Plant and machine operatives & 9.5 & 10.1 & 13.5 & 8.9 & 11 & 4.4 \\
& 100 & 100 & 100 & 100 & 100 & 100 \\
& & & & & & \\
\% in top three occupations & 40.8 & 34.9 & 22.5 & 35.7 & 40 & 48.5 \\
N & 32536 & 1634 & 524 & 395 & 420 & 295 \\
\hline
\end{tabular}


Table 2: Educational Distributions of Immigrants and Natives

\begin{tabular}{lrrrrrr}
\hline & & All & Arrived & Arrived & Arrived & Arrived \\
& Native & immigrants & $04-05$ & $02-03$ & $00-01$ & $95-99$ \\
\hline & $\%$ & $\%$ & $\%$ & $\%$ & $\%$ & $\%$ \\
No formal/ primary & & & & & & \\
education & 10.5 & 4 & 6.1 & 2 & 4.5 & 2 \\
Lower secondary & 16.7 & 8.4 & 5 & 9.6 & 8.3 & 12.9 \\
Upper secondary & 29 & 26.8 & 36.3 & 26.6 & 21 & 18.6 \\
Post Leaving & 12 & 10.4 & 11.6 & 10.6 & 9.5 & 9.2 \\
Third level & 11.8 & 13.6 & 13 & 13.2 & 13.1 & 15.9 \\
Third level - degree or & & & & & & 43.6 \\
above & 19.9 & 36.8 & 28.1 & 38 & 41.4 \\
& & & & & & 57.3 \\
\% third level & 31.7 & 50.2 & 41.1 & 51.2 & 56.7 & 57.3 \\
$\mathrm{~N}$ & 32536 & 1634 & 524 & 395 & 420 & 295 \\
\hline
\end{tabular}

Table 3: Nationality Distribution of Immigrants by Year of Arrival

\begin{tabular}{lrrrrr}
\hline & All & Arrived & Arrived & Arrived & Arrived \\
& immigrants & $04-05$ & $02-03$ & $00-01$ & $95-99$ \\
\hline UK & $\%$ & $\%$ & $\%$ & $\%$ & $\%$ \\
EU-13 & 23.1 & 10.1 & 20.3 & 22.4 & 51.2 \\
EU-NMS & 16.4 & 19.8 & 14.4 & 11.4 & 20 \\
USA & 27.7 & 52.9 & 25.6 & 16 & 2.4 \\
Other & 1.7 & 1 & 2 & 1.2 & 3.4 \\
& 31.1 & 16.2 & 37.7 & 49 & 23.1 \\
N & & & & & \\
Note: EU-13 refers to the EU-15 less the UK and Ireland & 1634 & & & & \\
\end{tabular}


Table 4: Probit Model of Occupational Attainment for all immigrants and all natives (Dependent variable: occupation is manager/professional/associate professional or otherwise)

\begin{tabular}{|c|c|c|c|c|c|}
\hline Variable & Marginal impact & Err. & $\mathrm{P}>|\mathrm{z}|$ & & \\
\hline Age $20-24$ & .09 & .02 & .00 & & \\
\hline Age 25-34 & .20 & .02 & .00 & & \\
\hline Age $35-44$ & .23 & .02 & .00 & & \\
\hline Age 45-54 & .24 & .02 & .00 & & \\
\hline Age 55-59 & .26 & .03 & .00 & & \\
\hline Age 60-64 & .27 & .03 & .00 & & \\
\hline Age 65+ & .43 & .03 & .00 & & \\
\hline Ed Lower secondary & .00 & .01 & .75 & & \\
\hline Ed upper secondary & .15 & .01 & .00 & & \\
\hline Ed post leaving & .14 & .01 & .00 & & \\
\hline Ed third level non-degree & .46 & .01 & .00 & & \\
\hline Ed third level degree & .70 & .01 & .00 & & \\
\hline Time with current employ & .01 & .00 & .00 & & \\
\hline Married man & .00 & .01 & .431 & $\mathrm{~N}$ & 33,489 \\
\hline Single man & -.02 & .01 & .01 & LR chi2(17) & $11,205.04$ \\
\hline Married woman & -.00 & .01 & .73 & Prob $>$ chi2 & .0000 \\
\hline Immigrant & -.10 & .01 & .00 & Pseudo R2 & .2637 \\
\hline
\end{tabular}

Table 5: Probit Model of Occupational Attainment for immigrants by year of arrival and all natives (Dependent variable: occupation is manager/professional/associate professional or otherwise)

\begin{tabular}{lllllr}
\hline Immigrants year of arrival & Marginal Impact & S.E. & $\mathrm{P}>|\mathrm{z}|$ & & \\
\hline $1995-99$ & -.002 & .028 & .935 & $\mathrm{~N}$ & 33,489 \\
$2000-01$ & -.086 & .019 & .000 & LR chi2(17) & $11,225.54$ \\
$2002-03$ & -.117 & .018 & .000 & Prob > chi2 & 0.0000 \\
$2004-05$ & -.134 & -.015 & .000 & Pseudo R2 & 0.2642 \\
\hline
\end{tabular}

Table 6: Probit Model of Occupational Attainment for immigrants by nationality and all natives (Dependent variable: occupation is manager/professional/associate professional or otherwise)

\begin{tabular}{lllllr}
\hline Immigrants nationality & Marginal Impact & S.E. & $\mathrm{P}>|\mathrm{z}|$ & $\mathrm{N}$ & 33489 \\
\hline UK & .050 & .027 & .056 & LR chi2(17) & 11331.88 \\
US & .011 & .102 & .914 & Prob > chi2 & 0.0000 \\
EU-13 & -.035 & .026 & .189 & Pseudo R2 & 0.2667 \\
EU NMS & -.230 & .010 & .000 & & \\
Other & -.084 & .017 & .000 & & \\
\hline
\end{tabular}


Table 7: Probit Model of Occupational Attainment for UK immigrants by year of arrival and all natives (Dependent variable: occupation is manager/professional/associate professional or otherwise)

\begin{tabular}{lllllr}
\hline Immigrants year of arrival & Marginal Impact & S.E. & $\mathrm{P}>|\mathrm{z}|$ & & \\
\hline $1995-99$ & .08 & .05 & .08 & $\mathrm{~N}$ & 31521 \\
$2000-01$ & -.02 & .05 & .64 & LR chi2(17) & 10707.25 \\
$2002-03$ & .05 & .06 & .35 & Prob > chi2 & 0.0000 \\
$2004-05$ & .1 & .07 & .14 & Pseudo R2 & 0.2656 \\
\hline
\end{tabular}

Table 8: Probit Model of Occupational Attainment for EU-NMS immigrants by year of arrival and all natives (Dependent variable: occupation is manager/professional/associate professional or otherwise)

\begin{tabular}{lllllr}
\hline Immigrants year of arrival & Marginal Impact & S.E. & $\mathrm{P}>|\mathrm{z}|$ & & \\
\hline $1995-99$ & -.01 & .15 & .94 & $\mathrm{~N}$ & 32008 \\
$2000-01$ & -.20 & .03 & .00 & LR chi2(17) & 10964.46 \\
$2002-03$ & -.23 & .02 & .00 & Prob > chi2 & 0.0000 \\
$2004-05$ & -.24 & .01 & .00 & Pseudo R2 & 0.2703 \\
\hline
\end{tabular}

Table 9: Probit Model of Occupational Attainment for EU-NMS immigrants by year of arrival and natives with third level qualifications (Dependent variable: occupation is manager/professional/associate professional or otherwise)

\begin{tabular}{lllllr}
\hline Immigrants year of arrival & Marginal Impact & S.E. & $\mathrm{P}>|\mathrm{z}|$ & & \\
\hline $1995-99$ & -.09 & .22 & .67 & $\mathrm{~N}$ & 9631 \\
$2000-01$ & -.39 & .08 & .00 & LR chi2(17) & 629.57 \\
$2002-03$ & -.33 & .08 & .00 & Prob > chi2 & 0.0000 \\
$2004-05$ & -.53 & .04 & .00 & Pseudo R2 & .053 \\
\hline
\end{tabular}

Table 10: Probit Model of Occupational Attainment for EU-13 immigrants by year of arrival and natives with third level qualifications (Dependent variable: occupation is manager/professional/associate professional or otherwise)

\begin{tabular}{lllllr}
\hline Immigrants year of arrival & Marginal Impact & S.E. & $\mathrm{P}>|\mathrm{z}|$ & & \\
\hline $1995-99$ & -.14 & .08 & .06 & $\mathrm{~N}$ & 9613 \\
$2000-01$ & .03 & .08 & .73 & LR chi2(17) & 454.11 \\
$2002-03$ & -.06 & .08 & .43 & Prob > chi2 & 0.0000 \\
$2004-05$ & -.17 & .06 & .00 & Pseudo R2 & 0.039 \\
\hline
\end{tabular}


Table 11: Educational Distributions of Immigrants by National Group UK EU-13 EU-NMS Other USA All immigrants

\begin{tabular}{lrrrrrr}
\hline & $\%$ & $\%$ & $\%$ & $\%$ & $\%$ & $\%$ \\
No formal/ primary education & 2.4 & 1.1 & 6.4 & 4.7 & 0.0 & 4.0 \\
Lower secondary & 18.3 & 2.2 & 9.3 & 3.5 & 7.1 & 8.4 \\
Upper secondary & 19.6 & 22.4 & 37.8 & 25.2 & 17.9 & 26.8 \\
Post Leaving & 11.4 & 8.2 & 14.6 & 7.1 & 10.7 & 10.4 \\
Third level & 15.1 & 14.2 & 12.6 & 13.6 & 3.6 & 13.6 \\
Third level - degree or above & 33.3 & 51.9 & 19.2 & 45.9 & 60.7 & 36.8 \\
& 100 & 100 & 100 & 100 & 100 & 100 \\
& & & & & & \\
$\mathrm{~N}$ & 378 & 268 & 452 & 508 & 28 & 1634 \\
\hline
\end{tabular}




\section{References}

Amuedo-Dorantes, Catalina and Sara de la Rica (2006), "Labor Market Integration of Recent Immigrants in Spain”, IZA Discussion Paper No. 2104

Antecol, Heather, Peter Kuhn and Stephen Trejo (2003), “Integration via Prices or Quantities: Labour Market Institutions and Immigrant Earnings Growth in Australia, Canada and the United States”, IZA Discussion Paper No. 802

Baker, Michael and Dwayne Benjamin (1994), "The Performance of Immigrants in the Canadian Labour Market”, Journal of Labor Economics Vol. 12 pp. 369-405

Barrett, Alan, Adele Bergin and David Duffy (2006), “The Labour Market Characteristics and Labour Market Impacts of Immigrants in Ireland”, Economic and Social Review Vol. 37 pp. 1-26

Barrett, Alan, John FitzGerald and Brian Nolan (2002), "Earnings Inequality, Returns to Education and Immigration into Ireland”, (2002), Labour Economics, Vol. 9 No. 5

Barrett, Alan and Yvonne McCarthy (2006), "Immigrants in a Booming Economy: Analysing their Earnings and Welfare Dependence”, IZA Discussion Paper No. 2457

Barrett, Alan and Philip J. O’Connell (2001), "Is there a Wage Premium For Returning Irish Migrants”, Economic and Social Review Vol. 32 No. 1

Barrett, Alan and Fergal Trace (1998), "Who is Coming Back? The Educational Profile of Returning Migrants in the 1990s”, Irish Banking Review, Summer pp. 38-52

Borjas, George (1987), "Self-Selection and the Earnings of Immigrants", American Economic Review Vol. 77 No. 4

Borjas, George J. (1985), “Integration, Changes in Cohort Quality and the Earnings of Immigrants”, Journal of Labor Economics Vol. 3 pp. 463-489

Central Statistics Office (2005), Quarterly National Household Survey Quarter 2 2005, Dublin: CSO

Chiswick, Barry R. (1978), "The Effect of Americanisation on the Earnings of Foreign-born Men”, Journal of Political Economy Vol. 86 pp. 897-921

Chiswick, Barry R., Yew Liang Lee and Paul Miller (2005), “Longitudinal Analysis of Immigrant Occupational Mobility: A Test of the Immigrant Integration Hypothesis”, International Migration Review Vol. 39 pp. 332-353

Green, David A. (1999), "Immigrant Occupational Attainment: Integration and Mobility over Time”, Journal of Labour Economics, Vol. 17 pp. 49-79

Honohan, Patrick and Brendan Walsh (2002), "Catching Up with the Leaders: The Irish Hare”, Brookings Papers on Economic Activity Vol. 2002 pp 1-57 
Minns, C. (2005), "How Skilled Are Irish Immigrants? Evidence and Implications", paper delivered to the Statistical and Social Inquiry Society of Ireland, 24 February.

OECD (2006), Education at a Glance, Paris: OECD. 